Euskal ikerketen aldizkaria | Revue d'études basques |

Revista de estudios vascos | Basque studies review

19 | 2016

Numéro XIX

\title{
Fourteen tests for Breton collectives, an inquiry into number and numerosity
}

Mélanie Jouitteau and Milan Rezac

\section{OpenEdition}

\section{Journals}

Electronic version

URL: https://journals.openedition.org/lapurdum/3444

DOI: 10.4000/lapurdum.3444

ISSN: 1965-0655

\section{Publisher}

IKER

\section{Printed version}

Date of publication: 1 January 2016

Number of pages: 357-389

ISBN: 978-2-95534-134-6

ISSN: $1273-3830$

\section{Electronic reference}

Mélanie Jouitteau and Milan Rezac, "Fourteen tests for Breton collectives, an inquiry into number and numerosity", Lapurdum [Online], 19 | 2016, Online since 01 January 2021, connection on 03 September 2021. URL: http://journals.openedition.org/lapurdum/3444 ; DOI: https://doi.org/10.4000/lapurdum. 3444

Creative Commons - Attribution - Pas d'Utilisation Commerciale - Pas de Modification 4.0 International - CC BY-NC-ND 4.0 


\title{
Fourteen tests for Breton collectives, an inquiry into number and numerosity \\ Mélanie JOUITTEAU and Milan REZAC CNRS-IKER
}

\begin{abstract}
We report on an inquiry into the mapping between the syntax and semantics of number in so-called collective nouns in Breton. First, the collective system of Breton is described. Next, we lay out the theory of numerosity (semantic) and number (syntactic) in terms of which we formulate particular diagnostics. We compare collectives to better or worse understood classes of nouns in the numerosity-number system, including group, count, and different varieties of mass nouns, focusing on those with anomalous number behavior recalling those of collectives. Each diagnostic is accompanied by the results of a pilot study. We review the methodological, comparative, and theoretical results we have and their current limits. ${ }^{1}$
\end{abstract}

\section{Introduction}

\subsection{Breton Collectives and the numerosity-number relationship}

The descriptive literature on Breton, the Brythonic Celtic language spoken in Brittany, gives collectives as one of the categories of nominal number, along with singulars, duals and plurals. Singulars and plurals, to a good first approximation, have the behavior and uses one would expect of English: for instance existential, generic, and kind uses of a bare plural like koadoù 'forests', kizhier 'cats', with plural agreement and anaphora, of the singular koad, kazh. Collectives are lexical items that behave in this respect like neither singular nor plural; they may be isolated by properties we illustrate for gwenan 'bees', gwez 'trees', stered 'stars' (e.g.

1. This article benefited from the great patience and generosity of J. Jade, A-M. Louboutin and M. Lincoln. Be they duly thanked here. The elicitation results are and on line at the Elicitation Center in http://arbres.iker.cnrs.fr. This research is partly founded by the FP7 Collaborative Project AThEME (GA 613465). 
Kervella 1947, Trépos 1957, Anderson 1986, Press 1986, 2010, Favereau 1997).

Morphology: collectives are not the inflectional plurals of any singular and often have no recognisable plural morphology, though historically some like stered are old plurals with lost singulars. Further, morphologically many collectives stand in a derivational relationship to singulatives formed from them by the suffix -enn, gwenan-enn 'bee', gwez-enn 'tree', steredenn 'star', which are themselves formally regular count nouns and pluralisable. ${ }^{2}$

Syntax: Collectives control strictly plural agreement. They also strictly antecede plural pronominal anaphora in any local or non-local relationship, a matter that at least partly belongs to syntax, and entirely on some approaches, for instance the reason that anaphora to scissors are plural is because they have the covert NP scissors (cf. Elbourne 2013 on gender). ${ }^{3}$

(1) A-boan ma'z eo en em zastumet mad ar gwenan el leac'h ma sonjont ober barely that PRT is REFL gathered well the bees in.the place that think.3p make o demeuranz, ma komansont raktal da labourat evid kempen o zi. their dwelling that begin.3p straightway to work for prepare their house As soon as bees have gathered in the place where they think to make their dwelling, they begin straightway to work in order to prepare their house. (Henri 1906)

Semantics: collectives are, well, «collective», in some sense that it is our aim to study. To a first approximation formed by descriptions and usage, the collective gwez is somewhere between and inclusive of 'trees' and 'forest', whilst the plural of the singulative gwezennoù is in its turn more restricted than one would expect given other count plurals. To hazard an impression, generic and kind Trees are tall (here), and vague existential Trees surround my house, as well as vague definite My house is in the trees, would all use gwez, while gwezennoù might be used for Some trees surround my house, Look: here we planted (your) trees. If that is right, analogues are known in the literature, even going by the term collective-distributive (Corbett

2. Regular plurals in Breton are typically formed with the suffix -où, but for certain categories -ed, -ien/-ion are regular, while a variety of plurals are semi-regular in attaching a recurrent suffix to the singular base or an umlauted variant of it, while others like tud 'people' are not related to any singular base. Collectives are either plainly unmarked, like gwez 'trees', or bear several recurrent markers that do not synchronically relate them to a distinct base but often historically are plurals, e.g. -ent in skevent 'lungs', singulative skeventenn 'lung'; -ien, -ion in kelien 'flies', glasien 'greenery', cf. glas 'green'; bili 'shingle(s)', an old internal plural. Some suffixes are semi-productive: -ez, in kerez 'cherries', attaches to borrowings, banan-ez 'bananas', singulative bananezenn; -en, salad-en 'salad(s)', singulative saladenenn. See Kervella (1947), Favereau (1997).

3. We omit the intricacies of Breton agreement; roughly, verbs and prepositions are 3s with any overt subject, save the verb have that agrees with them, but both have inflectional morphology reflecting the phi-features of silent subjects, demonstrably pronouns; for verbs this includes pre-negation subjects resumed by a silent pronoun. See Jouitteau and Rezac $(2006,2008)$ with literature. 
2004). At the same time, it is an impression, and one among others, notably a similarity between collectives and lexical plurals like oats, clothes (Acquaviva 2008), and plural-agreeing groups like The herd were grazing peacefully (Allan 1980).

Our interest is what the collective meaning of collectives might be in the gamut of number-related meanings, or numerosity, and how it relates to their syntactic plurality, or number. One way to approach the question is through a formal study based on the study of the distinctions of numerosity and number in other systems, the theories thereof, and the tests thereby made available for the study of unknown categories. To take an example, the nature of so-called object-mass or aggregate nouns like furniture is not a priori clear: in some ways they resemble prototypical mass nouns like water and in others plural count nouns like chairs. We can then pit it against properties on which masses and pluralities differ, like quantification, too much $/{ }^{*}$ many furniture, and reciprocity, * The furniture resembles each other, for both of which it is like water and not chairs, and distributive predicates, The furniture is square, where it is like chairs because it each piece of furniture must be square and unlike water that here makes no sense. From there, one can draw conclusions both descriptive and theoretical about the numerosity of furniture and its relationship to its singular number. Such studies have targeted one mystery category after another (Their committee is too small, Their clothes are too small, * Their wits are too small), contributing to the understanding of numerosity and number.

We report the tools we have so far found useful in such an inquiry into Breton collectives and report on a pilot study. Yet at this point, we are largely finding our way through territory some well mapped but new to us, some little explored. ${ }^{4}$

\subsection{Breton collectives among Breton nouns}

The descriptive literature leaves a certain ambiguity in what collectives are: necessarily, they are nouns that combine with plural agreement and anaphora without being the morphological plurals of singular counterparts, but depending on how one construes the idea of being a morphological plural of something else, that might or might not include the relationship of English person-people and its counterpart in Breton den-tud, usually distinguished from collectives (e.g. Kervella 1947: 336), though sometimes included (Trépos 1957: 122). Among nouns given as collectives are:

Plants and their parts: plant 'plants', geot 'grass', gwez 'trees', strouezh 'shrubs, shrubbery' trinchin 'sorrel', korz 'reed', ed 'cereal, wheat', gwinizh 'wheat', mais 'corn', mouar 'blackberries', sivi 'strawberries'; frouezh 'fruit(s)', kraoñ 'nuts', greun 'grain(s)', patatez, tomatez, karotez 'potatoes, tomatoes, carrots';

4. Corbett (2004) reviews numerosity and number cross-linguistically; we will frequently advert to their relationship across the count-mass divide, where general overviews of the cross-linguistic situation include Wierzbicka (1988), Acquaviva in (2008), Doetjes (2011), Massam (2013, ed.). 
Small animals:

Large animals: Inanimate nature: Artefacts: deil 'leaves, foliage', bleuñv 'flowers', struj 'shoots, growth', had 'seed(s)' c'hwibu/fubu 'midges', merien 'ants', kelien 'flies', laou 'lice', gwenan 'bees', buzhug 'earthworms', logod 'mice', istr 'oysters', meskl 'mussels', nez 'nits' moc'h 'pigs', chatal 'cattle' blev 'hair', reun 'horsehair', bruzun 'crumbs', bili 'shingle(s)' dilhad 'clothes', pilhoù/truilhoù 'rags', krampouezh 'crepes', arc'hant 'money'

The classes are revealing both for what they contain and what they do not, in comparison to English and French object mass nouns and lexical plurals with clear sizable pieces (furniture, furnishings, clothing, clothes), or small granular ones (rice, oats, shingles), or meshes (hair), perhaps biased towards the biological but ranging over inanimate nature and artefacts as well, but usually not substances (like water, fumes), abstracts (like courage, wits), or spatiotemporal extents (like space, barrens, vacations).

Trépos (1957: 219) describes the meaning of collectives as «confused mass, in which it is difficult to discern units», illustrating with 'hair', 'ants', 'shingles', but also 'trees'. ${ }^{5}$ It seems vain to go looking for a physical or cultural property deterministically coupled to whether a noun is collective, as much as in the familiar count-mass divide. We assume that one cannot say much about the botany from the massiness of fruit but not vegetable, nor the dietary habits of English as opposed to French speakers, or at best pose as a question whether the plurality of oats might «point to oats being eaten originally in the grains, not, like wheat and barley, in the form of meal or flour» (Oxford English Dictionary s.v. oats). So it is for collectives: if logod is a prototypically collective, razh 'rat' is a prototypical count singular with a regular plural razhed, and though reanalysis does occur in varieties of Breton to shift their categories, we suspect it does not speak to these animals population statitics. At best, collectives are used for objects that tend to be construed in groups (Irslinger 2014: 95), to the same degree one can make similar generalisation of masses in English or French.

Accordingly, the classes into which collectives fall are not exclusively the purview of collectives in Breton, for it also has the counterpart of count and mass singularia tantum that English and French use here:

Group count singulars: Breton has regular, pluralisable count nouns used for groups, familh 'family', but also productive suffixes forming group nouns, notably -ad, general as in stroll-ad 'collect-ion, group', bandenn-ad 'group-ful, group', dorn-ad 'hand-ful', and -eg particularly forming names of collections of plants; drez collective 'brambles', drez-eg both 'a plant of brambles' and 'blackberry-bush'.

Mass singularia tantum: Collectives often correspond in meaning to mass nouns, but inversely, there are mass singulars with meanings similar to collectives, gwer 'glass' (Acquaviva 2008: 257), keneud 'dry wood' (Trépos 1957: 122), foen 'hay' (Kervella 1947: §336), bezin 'seaweed' in (2). Plant names like ed 'cereal, wheat' show variation between being collectives

5. Translations are ours. 
and singularia tantum, recalling the English type garlic count and mass (Favereau 1997: §78). So do plant products, greun 'grain(s)', like fruit. We do not know how far the comparison goes: koad is both a substance singulare tantum 'wood' and a collective 'trees', close to the ambiguity of wood itself (Plourin 1982: 552, confirmed by M3), but not identical as collective koad but not count wood may be used of a tree-row (4). ${ }^{6}$

(2) Ar bezin 'oa goulenn dezhañ.

the seaweed was request of.him

'There was a demand for seaweed.'

Merser (2011:13)

(3) Ar c'hoad-se ne zeu tamm gor ebet diouto.

the wood-here neg comes piece heat at.all from.them

'This wood does not make good firewood.'

Menard and Kadored, (2001:'koad)

(4) ul lec'h bordet a goad tilh

a place edged of wood lime

'a place bordered with lime trees.' idem.

(5) An ed n' \{int/eo\} ket azw. Ar mais n' \{int/eo\} ket uhel awalc'h.

the cereal neg are/is not ripe. the corn neg are/is not high enough.

'The cereals are not ripe. The corn is not high enough.'

Favereau (1997:§78)

Perhaps the commonest formal diagnostics given for collectives, distinguishing them from the den 'person' - tud 'people' pair, is their association with singulatives derived from them by the suffix -enn and meaning the objects that are assembled in the collective. However, -enn is a general derivational suffix, attaching not only to collectives, but also to ordinary count singulars, count plurals, and mass singulars, subject to caprices of meaning across these categories, and not automatically available with any (Favereau 1997: §77ff., Jouitteau 20092015 s.v. -enn). Prevalently, collectives like gwez 'trees', masculine as all collectives, do have singulatives in -enn, feminine, which pick out what they seem to collect, gwezenn 'tree'. Some collectives however do not have singulatives in this sense: arc'hant 'money' is considered as a typical collective, being an underived plural-agreeing noun, but arc'hant-enn does not mean 'coin, bill'; it can mean 'roundel argent' (a motive in heraldry), likely as absent from many mental lexicons as roundel argents were from ours. In turn, -enn attaches with this meaning

6. The 'gold' substance is not usually treated as collective, but cf. the plural anaphor in (i)

(i) Honnez, hag e ve leiz an daol a aour, na finvo ket anezho. (Treger, Gros 1970b: §'leiz') this.one and $\mathrm{R}$ is full the table of gold neg move neg P.them

'This one, even if the table was covered with gold, would not touch it (\#them)'. 
or an idiosyncratic one to count singulars, kalon 'heart' - kalon-enn, lod 'part' - lod-enn, with about the same meaning; rarely (semi-)regular count plurals, razh-ed 'rat-s', razhed-enn 'rat'; irregular count plurals, tud 'people' - tudenn 'character, personage'; mass singulars, traezh-enn 'sand, beach' - traezhenn about the same but more commonly beach, boued 'food' - boued-enn 'edible part (of a shellfish)' (examples from Kervella 1947, Trépos 1957, Favereau 1997, Goyat 2012). Similarly, the object that a collective collects may be extracted by means of a classifier-like noun like pezh 'piece', penn 'head', loen 'animal', but this too does not discriminate between collectives and plurals. Traditionally collective ognon 'ognion(s)', traditionally semiregular plural deñved 'sheep' and irregular plural kezeg 'horse', form penn-ognon, penn-deñved, penn-kezeg for a single 'ognon', 'sheep', 'horse' (ibid.).

Morphosyntactic criteria then leave it open whether there is any distinction between den 'person' - tud 'people' and collectives, and more generally, whether collectives might not simply be plain count plurals that are simply pluralia tantum, that is that are idiosyncratically missing count singulars, as people might be. Yet this very example illustrates one possibility of what might lie behind the distinction. While people seems now to behave as a plural count noun semantically, prescriptive grammars prefer to count with persons, and that difficulty with counting is synchronically very clear with cattle, more so with police, though other tests will reveal these are very close to count plurals, neither mass nor group. Something like this might be reflected in the repeated mentions of the collectivity and indiscernability of collectives. Descriptions do not go further, or go further into mysteries: to take Trépos (1957: 252), the standard singulative plural steredennoù of the standard collective stered 'stars' gives «greater individuality», as apparently does in Trépos's own Plozévet dialect stered itself (a collective or plural of ster 'star', as it is historically?) compared to collective steyr (historically, another plural of ster). Against this insistence on the distinction between collectives and count plurals, there is to be set that in other ways they are closer to regular count plurals than the plurals of their singulatives N-ennoù, for these show a curious restriction to small, discrete quantities recalling the distributive-collective systems like that of Mohawk (Corbett 2004: 4.4). A common translation of the singulative plural is with an explicit 'some': Le Roux (1927: map étoile(s)) glosses steredennoù 'quelques étoiles, some stars', Favereau (1997: §83) gives (6), and Kervella (1947: 8338) says «A collective is thus used as a general plural, and the plural of the singulative as a narrow plural. To say koumoulennoù [plural singulative of koumoul 'clouds'] is as if to say ... a few clouds». Henri's (1906) manual of bee-keeping never once uses the plural of the singulative gwenanenn 'bees' since his talk of bees in all of kinds and generalisations, for which the collective gwenan is used, though for ordinary count nouns the plurals have these uses.

(6) «The meaning of -ennoù can be along the lines of some [quelques], ur yar wenn gant pluñv-enn-où du war he goûg»

a chicken white with feather.coll-SG-PL black on her neck

'a white chicken with some black feathers on her neck' (Favereau 1997: §83)

1.3. Where are the collectives?

Grammars give the impression of a stalwart category of collectives with collective-singulative-singulative plural triplets and a substantial core of shared items. We aim to look first at such triplets, in order to single out the traditional class of collectives, and to compare the 
collective not only with regular count plural, but with the plural of its singulative N-ennoù .

We have not found it as easy as that to find triplets, a perhaps unsurprising fact: a closer look at corpora reveals that plural singulatives are rare, and the pairing of a plural-agreeing underived noun with a singulative itself may come and go from dialect to dialect and period to period. An example of such variation is the dialectal and diachronic variation of collective stered 'stars', originally the plural of ster 'star', in the table in (7). The historical situation here is unclear, but revolves around ster 'stars', stered formed on it as if by a common plural suffix -ed, stir another originally common plural with i-umlaut, and derivatives in -enn to all these as if singulatives of collectives (see e.g. Trépos 1957: 252). The following table resumes the situation in a number of sources, illustrating the independence of the -enn formation from any of the collective bases.

(7) Documented forms for the noun denoting 'star(s)'

\begin{tabular}{l|lll}
\hline & 'stars' & 'a star' & '(some) stars' \\
\hline & $\mathrm{N}$ & + SG & $+\mathrm{PL}$ \\
\hline Le Bayon (1878) & stir & stiren & stired \\
\hline $\begin{array}{l}\text { Gwened } \\
\text { according to Le Roux (1927) }\end{array}$ & $\begin{array}{l}\text { ster } \\
\text { stir }\end{array}$ & sterenn & stireneù \\
ancient KLT \& & chtir & chtirenn & chtirenneù \\
some Kerne areas & ster & & \\
de Rostrenen (1732) & stered & sterenn & sterennoù \\
Trépos (1957:252), Plozévet & stéyr & ? & stered \\
Goyat (2012:189), Plozévet & stered & steredenn & \\
actual standard \& KLT & stered & steredenn & steredennoù \\
\hline
\end{tabular}

Up to this point, we have interviewed three native speakers of the KLT western dialects, of different localities and ages. Our first elicitation with J., 87, from Mahalon/Esquibien (Kerne), did not identify any triplets, with typical ones like that of logod 'mice' missing one or another member. Our second, with A-M., 80, from Locronan (Kerne), also failed for most triplets, steredennoù in particular being given as known but not used by the speaker. A control count plural, razh 'rat' - razh-ed 'rat-s', turned out to yield what seems to be a collective triplet: the old singular razh is missing, and the plural rayed [= standard razhed] is coupled with count singular rayedenn, plural rayedennoù (cf. Le Roux 1927: map 545, Trépos 1957: 243, Favereau 1997: §80).

(8) In search of tripartite oppositions for A-M. (Locronan) 


\begin{tabular}{l|lll}
\hline & $\mathrm{N}$ & $+\mathrm{SG}$ & $+\mathrm{PL}$ \\
\hline pear(s) & per & perenn & * perennoù \\
mouse, mice & logod & logodenn & *logodennoù \\
\hline star(s) & stered & steredenn & * steredennoù \\
$\operatorname{rat}(\mathrm{s})$ & raed & rayedenn & rayedennoù \\
\hline
\end{tabular}

The third speaker M., 26 from the Leon dialect, had some plural-agreeing underived lexemes that are traditional collectives, but without singulative plurals in -enn-où: buzug, 'earthworms', kelien, 'flies', gwenan, 'bees' or istr, 'oysters'. She had plurals in -enn-où missing a potentially collective base (klogorennoù/*klogor 'blisters' and orjalennoù/*orjal 'wires'), or lexemes missing the singulative singular (she reported discomfort with the singulative form frouezhenn 'fruit'). Some double plurals lacked the singulative brujun(*enn)où 'crumbs'. We did end up with the following triplets over three sessions:

(9) In search of tripartite oppositions for M. (Leon/Diwan)

\begin{tabular}{l|lll}
\hline & $\mathrm{N}$ & $+\mathrm{SG}$ & $+\mathrm{PL}$ \\
\hline pear & per & perenn & perennoù \\
hair & blev & blevenn & blevennoù \\
plant(s) & plant & plantenn & plantennoù \\
midge(s) & fubu & fubuenn & fubuennoù \\
\hline star(s) & stered & steredenn & steredennoù \\
crumbs & brujun & brujunenn & brujunoù \\
\hline
\end{tabular}

Of these, we tend to set aside here blev 'hair(s)', because of a mix of singular and plural behavior rather than plural alone, which we take as a sign blev has for her occasional mass uses. We remain suspicious of the results for the recent French borrowing plant 'plants' because of apparent ambiguity with a count singular 'plant' (cf. French plante 'plant' count only). Hence the central role played in our report by fubu 'midges'.

\section{Numerosity}

To formulate tests for numerosity, we will need to talk in terms of a particular theory of it. This section aims at providing a sketch of one approach to count nouns and two to mass 
nouns, which we pick as the ones that seem to us to be the most widely familiar.

For count nouns, we use the lattice theory of Link (1983), modified by the theory of groups of Barker (1992); more formal overviews and comparisons with alternatives are Nouwen (2015), Scha and Winter (to appear). All nouns are properties of objects from the domain of individuals $\mathrm{D}_{\mathrm{e}}$, which thus includes individuals in the denotation of each of $d$ warf, dwarves, group of dwarves, infantry, water, space, beauty, kilo. The domain of individuals is closed under the binary operation sum, notated +, so that for any two individuals in it, say Gwen and Edurne, there is a uniuqe third individual that is their sum, Gwen+Edurne; plausibly, these are the denotations of the words Gwen, Edurne, and Gwen and Edurne. Sum yields 'flat' structures, so that Gwen+Edurne with Wapun is Gwen+Edurne+Wapun, like the sum of Gwen with Edurne+Wapun. ${ }^{7}$ Sum induces a partial order on the domain of individuals, the part-of relation, symbolised $\leq$, whereby Gwen+Edurne+Wapun has as parts any individual it is summed with to give itself and all their parts: Gwen+Edurne+Wapun, Gwen+Edurne, Gwen+Wapun, Gwen, Edurne, and Wapun. Individuals that have themselves as their only part are atoms with respect to $\leq$. All others, or proper sums, we shall call pluralities. Together, atoms and pluralities are sums.

The denotation of a plain singular count noun like woman is a property of atoms, such as Gwen. The cumulative operator * gets us to the denotation of the plural women. * takes a predicate, say the denotation of woman that in a particular situation holds of \{Gwen, Edurne, Wapun $\}$, and closes it under sum, to give $\{$ Gwen, ... Gwen+Edurne, ... Gwen+Edurne+Wapun $\}$. There is debate as to whether the denotation of women is just that, or whether the atoms are removed to leave just the pluralities. In either case, plural count nouns are cumulative: if women holds of Gwen+Edurne and Edurne+Wapun, it holds of their sum, Gwen+Edurne+Wapun, while woman holds of Gwen and Edurne but not their sume Gwen+Edurne. * tells us how to get from the denotation of a singular count noun to that of a plural one, but it does not mean that * or the cumulative structure it yields chracterise the meaning of the morphosyntactic feature [plural], though that would be nice. English and French abound in so-called lexical plurals that are the plurals of no singular or not related to their singular by cumulativity, so it would seem, nor will they prove to pass tests for it: dregs, clothes, groceries, remains, news, trousers, barrens, heavens, manners, thanks, measels, Pyrenees... Something more needs saying (see e.g. Ojeda 2005, Acquaviva 2008, Gillon 2012).

We also need to say something about how VPs apply to arguments denoted by DPs with singular and plural count nouns. Let us take Gwen and Edurne yawned, and assume that the subject denotes the plurality Gwen+Edurne, and the VP the property $\mathbf{x}$. $\mathbf{x}$ slept that can only hold of atoms. One way to get this atom-denoting VP to combine with the subject plurality is to apply * to the denotation of the lexical item yawn: if sleep holds of Gwen and of Edurne, then *sleep will hold of Gwen+Edurne; call it lexical cumulativit. We get the same results by applying * to the VP, but this latter move is needed to get the right meaning in more complex cases. An alternative to *-ing the VP is the silent distributive operator ${ }^{\mathrm{D}}$ below, which combines with the VP, the subject, takes each atom in the subject, and feeds it to the VP. For

7. Thus sum is associative; it is also commutative, $a+b=b+a$, and idempotent, $a+a=a$. 
our purposes, the difference between it and *-ing the VP will not matter, but the distributive operator lends itself better to our discussion.

$$
\begin{aligned}
& \mathrm{D}=\lambda \mathrm{X}_{\mathrm{e}} \lambda \mathrm{p}_{\mathrm{et}} \cdot \ll \mathrm{x}[\mathrm{x} \leq \mathrm{X} \& \mathrm{x} \text { is an atom } \rightarrow \mathrm{p}(\mathrm{x})] \\
& \left(\mathrm{x} \text { is an atom }:=\varnothing \exists \mathrm{y}\left[\mathrm{y} \leq \mathrm{x} \& \mathrm{y}^{1} \mathrm{x}\right]\right)
\end{aligned}
$$

Among atoms, some are distinguished because they are intuitively constituted of other individuals, but not as sums thereof. An example is the atom denoted by the group of Gwen, Edurne and Wapun in a particular situation s, call it $\mathbf{g}$. We call such group atoms simply groups, and reserve the term atom for other or pure atoms. Assume that there is the member-of function $f$ that is defined over groups and yields for each in a situation the individual (usually a plurality) that constitutes the group in a situation, $f(g)=$ Gwen+Edurne+Wapun. Because groups are atoms independent of their members, different properties can hold of the two: in the following sentences, the Pohjola club and it cannot be exchanged with their members, Gwen, Edurne and Wapun or the members of the Pohjola Club. All this goes for inanimate groups, This deck of cards has a card missing but not \#These fifty two cards have a card missing.

(11) In 2014, Gwen, Edurne and Wapun formed the Pohjola Club; it had three members

In 2015, the Pohjola Club went to Pohjola without Gwen, because she was sick. By 2016, the members of the Pohjola Club were becoming too different from each other, and it dissolved.

Group nouns like group, group of Gwen, Edurne and Wapun and Pohjola club are just like count nouns, singular and plural, but happen to hold of groups, that is of atoms in the domain of $f$. Because they hold of groups, that is group atoms, Because group nouns hold of groups, they are not cumulative, just like singular count nouns: if club holds the Pohjola club and of the Kalevala club, it need not follow that there is a sum of the two that is also a club. Among group nouns, there may be important distinctions that we advert to later (see recently Henderson 2014, Pearson 2011). In some but not other varieties of English, and not at all in French, some singular group nouns can control plural agreement and then behave as pluralities: The committee is ( ${ }^{*}$ each) old gives the age of the committee, and more marginally that of its members, whilst The committee are old gives only the age of the members. Yet this very phenomenon reveals another gap in our understanding of the relationship between morphosyntactic plurality and the theory of pluralities, and we return to it.

More or less complementary to count nouns are mass nouns, a term we use to a first approximation to cover those that, in English, are quantified by much/little rather than many/ few, and including:

(12) (i) substances of varying granularities: time, space, ether, water, silver, fruit, cake, sand, gravel, corn, hair...

(ii) object mass nouns (aggregates) that seem to come in clear smallest pieces: furniture, mail, luggage, silverware, ammunition, infantry...

(iii) abstracts: courage, knowledge, thinking, beauty, syntax... 
Mass nouns do not make distinctions of number; in English and French most are singular, and plural candidates like brains, oats, ashes either have no singular or do not seem to relate to it «regularly» by *-cumulation. There is a large number of closely similar mass-count pairs that lets us compare their properties: (we append * to those that are both mass and count): change - coin; mail - letter; carpet - carpeting; furniture -furnishings (lexical plural); fruit* vegetable; corn - pea; foliage - leaf; baklava - croissant; success ${ }^{*}$ - failure; infantry - footsoldier. There are also conversions of nouns between mass and count, some lexicalised, fruit, cake, hair, success, belief, success, but not say vegetable, fur, failure, others by more or marked application of the «universal grinder» and «packager».

We sketch two approaches to mass nouns, based on contrasting guiding intuitions about their nature; they and others are reviewed in e.g. Krifka (2007), Rothstein (2010), Lasersohn (2011), Doetjes (2011), Gillon (2012) with external perspectives in e.g. Barner and Snedeker (2005), Papafragou (2005), Nicolas (2012), Steen (2012). On one view, call it monist, mass nouns are close to plural count nouns, and they do indeed share striking properties against singular count nouns. Both support cumulativity: if something is baklava (mass) or croissants (count), and something else is too, then their sum will also be baklava or croissants. Both can appear bare in English and then are used as existential, Baklava/Croissants will be available, generic Brownies/Baklava need(s) butter, and kind Croissants evolved from baklava. Both can use the same «measuring» constructions, two kilos of, two pieces of... However, we also want to capture the differences -- after all, mass and not plural count nouns are singular, combine with much quantifiers, do not combine with cardinals, and so on. One influential proposal, that of Chierchia (1998ab), is at heart as follows: whilst a singular noun like chair holds lexically only of atoms, and must be pluralised by * to chairs to hold of the sums of those atoms plus have the atoms removed, furniture holds lexically of both atoms and their sums. Many similarities and differences get an elegant explanation. Among similarities, cumulativity is immediately guaranteed. Among differences, applying * cumulatoin would be vacuous, and so the singularplural distinction is otious in the measure it reflects the atom-plurality distinction. More subtly, counting masses is expected to be impossible if counting relies on there being a predicate that identifies the atoms to be counted: with count nouns there is, namely the singular chair of chairs, but with mass nouns the atoms and the pluralities all belong to a single predicate, furniture. It is worthwhile to mention one more technical aspect of the proposal, because it illustrates a relationship between different categories of numerosity: as a singular definite, we might want the furniture to hold of atoms rather than pluralities, and can let it do so by making available a conversion that takes a plurality, in this case the plurality that includes all individuals that count as furniture in a situation, to the group (group atom) to which it relates by $f$. The differences among mass nouns are not part of the ontology; water differs from furniture only because it is less clear what count as an atom of it: if we accept water is wet, there are bits that are wet and no parts of them are, but we have trouble identifying them.

The other view of mass nouns, call it dualism, holds that mass nouns hold of a separate domain of individuals than count nouns; we will sketch a proposal based on Link (1983). Let us suppose that our domain of individuals consists of just two atoms, of both of which count noun fruit holds, $a$ and $b$, so that fruits holds of $a+b$. Suppose now that for every such «count» individual of which a count noun holds, there is a distinct individual to which the former is relatable by a function $m$, the «stuff» of which it is made: $m(a)=x, m(b)=y, m(a+b)=z$. The mass noun fruit holds of these «mass» individuals. These mass individuals are not related to 
their count counterparts by + (and thus by $\leq$ ): $z$, the stuff of $a+b$, is not the + sum of $a, b$, nor is $a+b$ the + sum of $x, y$. But the mass individuals are themselves organised by an analogue of + (inducing $\leq$ ), call it $+_{\mathrm{m}}$ (inducing $\leq_{\mathrm{m}}$ ), with one key difference. The domain of count individuals is atomic with respect to $\leq$ : any individual is related by $\leq$ to the atoms of which it is the closure under + . The domain of mass is not atomic: there may be individuals that are closures under ${ }_{\mathrm{m}}$ of atoms with respect to $\leq_{\mathrm{m}}$ but there may be others that are not. Thus in our example, $z=$ $x+{ }_{m} y$, and so $x \leq_{\mathrm{m}} z$, but whereas $a$, to which $x$ corresponds under $m$, is an atom, $x$ need not be, but may be rather the $+_{m}$ sum of two smaller individuals, call them $x^{\prime}$ and $x$ ", and these too may be sums, and so on, with no atoms «at the bottom». The mass noun fruit holds of $z$ and all that relates to it by $\leq_{m}: x$, but also $x^{\prime}$ and $x "$, and so on. The individuals of which furniture holds plausibly do have atoms with respect to $\leq_{\mathrm{m}}$, those of ether perhaps not. Non-atomicity allows for total homogeneity: if $x$ is a part of water then $x$ is water; but non-atomicity is not required of masses and so need not hold of furniture. Like monism, dualism is quite successful at dealing with many basic properties of the count-mass distinction. Again cumulativity is guaranteed, pluralisation can be thought of as otious, and counting is out if it relies on identifying atoms by proper sums through $\leq$.

The theory of numerosity now gives us the following categories of nouns against which to pit collectives, each with richly documented properties to compare:

\section{Count singulars and their plurals: Group singulars and their plurals: Mass singularia tantum:}

\author{
chair, chairs. \\ team, teams. \\ $\operatorname{space}\left({ }^{*} s\right)$, furniture $\left({ }^{*} s\right)$, courage $\left({ }^{*} s\right)$.
}

The theory also has gaps in coverage, such as pluralia tantum of the scissors type, a plural that holds of atoms in a way knives does not. They illustrate an apparent mismatch between numerosity and number. Two such mismatches, both difficult at present, are of particular interest to us because of their resemblance to collectives.

One are lexical plurals that are so to speak on the border with mass nouns: on the one hand by their meaning, on the other by marginal availability of quantification with much when they are in non-agreeing contexts, and by resistance to quantification by many and counting by cardinals in general. Examples are ashes, snows, oats, dregs, fumes ; groceries, goods, belongings, leftovers ; brains, guts, wits, smarts, looks ; news, minutes, letters ; profits, dues ; vacations, nuptials ; barrens, deeps, narrows, heavens, (territorial) waters ; and the irregular plurals cattle, police. Some are plurals of stems that otherwise occur only as adjectives or verbs (or not at all), others are plurals of count nouns with a different meaning, others of mass nouns that they somehow intensify or otherwise modify, and all are lexicalised so that there is no *broads beside narrows, *stupids beside smarts, *shoppings beside belongings (see Acquaviva 2008 with further literature).

The others are plural-agreeing groups, like The committee are old. With plural agreement, there are some striking behaviours that make it seem as if committee denoted members of the committee, a regular count plural (Barker 1992). Yet it fails to bear plural morphology and is singular for adnominals, this/*these/*all committee are...; it fails to combine with quantifiers for plural nouns like most, keeping rather to ones for singular nouns like every; and to some extent, it can bind both singular and plural pronouns (Elbourne 1999). This somewhat mysterious pluralisation seems to extend to a noun of which we make extensive use, infantry, 
because it is as a singular an object mass noun rather than a group noun to go by known diagnostics:

(14) (Too much / $\varnothing /$ The) infantry is old. (cf. *Too much / $\varnothing /$ The army is old.) *This infantry of rangers is old. (cf. This army of rangers is old) $\%$ The infantry are old.

\section{Testing numerosity in Breton}

\subsection{Introduction}

Breton collectives are not themselves the morphological plurals of anything, yet take plural agreement and antecede plural pronouns: ${ }^{8}$

$$
\begin{array}{lr}
\text { Ar }\{\text { fubu, plant, stered }\} \quad n^{\prime}\{\text { int } / * \text { eo }\} & \text { ket glas. } \\
\text { the midges plants stars neg are } / \text { is } & \text { neg blue } \\
\text { The midges/plants/stars are not blue. } & \text { [M3] }
\end{array}
$$

Plural agreement on the verb might be a matter of morphosyntax with no interpretive correlates, but that of pronouns is a different matter. On any theory of pronouns, it reflects number visible to interpretation: either the number interpreted on their antecedent, or number on pronouns as individual variables, or number on a definite with a silent NP that pronouns reflect. Collectives are then interpretively [plural], and our question is how that relates to their numerosity. At one end of the range of possibilities, [plural] on collectives and count plurals have the same meaing, perhaps cumulativity, perhaps something quite different. At the other, there is still a single [plural] feature, but the interpretation is as unlike as it seems to be for [feminine] on fille 'girl' and chaise 'chair' in French, for for that matter [plural] on $2^{\text {nd }}$ person plural and $2^{\text {nd }}$ person singular polite vous. Any conclusion across this spectrum is of great interest for understanding the nature of the relationship between numerosity and number.

English lexical plurals and plural-agreeing groups illustrate how to go about probing the numerosity of collectives and how difficult it might be to interpret the results. Like collectives, lexical plurals are plural in agreement and for anaphora, but are not plurals of any singular, though they do not have singulatives. Like collectives, they give the impression of being less, well, transparent for what makes them up than plain count plurals. The impression can be probed: even the most «articulated» ones like clothes, groceries, oats resist cardinals and less so many quantifiers, and some are hopeless with them, yet for reciprocals for instance the internal structure is more visible than that of any mass or group noun:

8. See the introduction of agreement with pronouns in various position; our example here also turns out to involve a pronoun rather than agreement, as in Breton agreement by a preverbal subject across negation needs pro (Jouitteau and Rezac 2006). 
(16) $\varnothing / *$ Five / ?Many /*Much / $\varnothing$ clothes in this pile are clean, aren't they?

$\varnothing / *$ Five $/ *$ Many $/ *$ Much wits are surely not needed, are they?

(17) ? Clothes made out of velcro would stick to each other.

* Clothing made out of velcro would stick to each other.

Our tests all revolve around «looking inside» collectives, and that can apparently occur in a variety of ways: cardinals cannot look inside clothes to count individual items of clothing, but reciprocals to some extent can. Better-studied categories of numerosity design a multitude of such contrasts: be round can look at the pieces inside the mass noun of This furniture is square, but not inside the group noun This collection of furniture is square, neither can be counted by five or many like Five/many pieces of furniture are square, but only the group noun is opaque to Count the ( ${ }^{*}$ collection of) furniture. We have here a way of finding out what might lie behind staple of traditional descriptions of collectives as nouns that qu'on ne pet pas penser à énumérer «that one cannot think of ennumerating» (Trépos 1957: 221): can one really not count the collective arc'hant 'money', or can one simply not count it by cardinals?

We shall run through the tests we have found useful in the order that facilitates explaning them, and start with the ones we understand better and can say more about. The results of our pilot study are summarized in a table in the Appendix, but the aim of our discussion is to bring out the potential of the tests in future work. ${ }^{9}$

\subsection{Floating quantifiers}

Floating quantifiers are a prototypical test relying on gettig at the atoms of sums by the part-of $\leq$ relation. Indeed, we shall simplify with much of the literature by taking the floating quantifier each to simply spell out the distributive operator ${ }^{\mathrm{D}}$, though it probably imposes additional restrictions on event structure (cf. Junker 1995, Tunstall 1998). Unlike each, all can be distributive or collective, as in The girls are all building a raft, but there are meanings for it where it relies on ${ }^{D}$ like each (Brisson 2003). These floating quantifiers are readily compatible with pluralities. They are incompatible with groups, as expected on the atomic analysis of groups where they relate to their members by $\mathrm{f}$ but and not $\leq$, save when the group controls plural agreement in some varieties of English. Tellingly, floating quantifiers are also strictly incompatible with mass nouns of any sort, even object mass nouns, so these too do not seem to have atoms reachable by $\leq$.

(18) The members of the jury are each/all helping Gwen.

The jury is (*each/*all) helping Gwen.

The pieces of the furniture have each/all come from Ikea.

The furniture has $(*$ each/*all) come from Ikea.

9. We make a pass at present at a couple of tests we have tried: bare nouns and equatives with plural DPs. 
Floating quantifiers are curiously finnicky about their antecedent. One well known restriction is that they essentially need referential antecedents (Hoecksema 1997). Less widely studied is their resistance to arbitrary they (Kayne 2010). Perhaps relatable to the latter is their resistance to certain lexical plurals, cattle, police, though not others, people. There is an intuition that cattle makes its constituents less salient than cows, and under cardinals we discuss how that might be while still keep them predicates of sums of atoms. The badness with object-mass nouns might be related. The reciprocal diagnostic to follow shortly controls for whatever is going on here.

(19) John went to the post office. They ${ }_{\text {arb }}$ (\#each) told him to come back later.

(Kayne 2010)

Our cows/?cattle/??police have each been vaccinated against rabies.

When trying to test floating quantifiers in a new language, there is a number of confounds. The syntax of floating quantifiers remains under live debate (Fitzpatrick 2006, Cirillo 2009, Kayne 2010). One issue the syntactic relationship needed to their antecedent. Another is whether they might not apply to their antecedent through a silent pronoun. This last possibility is particularly relevant to us, because mediation of a clear pronoun, overt or $\mathrm{PRO}$, does let floating quantifiers to apply to groups, $(\mathrm{x}-\mathrm{b}, \mathrm{c})$, simply because a pronoun can accommodate reference to the members of an antecedent group $(x-a)$. It seems that bare floating quantifiers in English do not have this option, but that needs establishing for Breton.

(21) The pack stopped when they were hungry.

?The jury was none of them too happy with the verdict.

The team is (*each) hoping PRO to be (?each) able to hit a/their target.

A second confound is concord. In French, chacun is singular, but tous plural, and accordingly only chacun can combine with antecedents that denote pluralities but are not plural (Rezac and Jouitteau 2015 on the impersonal pronoun on). The third confound is related: in English and French both, there is a middle-field adverb all/tout, singular in French, with quite different meaning in principle but not always in practic from the floating quantifier, and its availability might ameliorate the floating quantifier with groups (Kayne 2010).

Turning then to Breton, we have tested holl 'all', which seems to be a middle-field floating quantifier like all/tous and with similar relationships to adnominal all/tous (Jouitteau 2009-2015:'holl'). Floating holl is fine with plurals, including the irregular plural tud, but not groups, whether simplex or derived by the suffix -ad. Unexpectedly, it is good with the sole object mass noun with have tested, arrebeuri 'furniture': it is a mass noun by its singular for agreement and pronouns and by a couple of other hints we shall see, but it will also prove to behave strictly as a count plural for access to atoms. When we turn to collectives, holl is good with the plurals of singulatives derived from collectives, but also fundamentally with collectives themselves. It is a first, yet strong, hint of a behavior comparable to plural count nouns on the part of collectives. 
(22) $\operatorname{Ar}\{\sqrt{ }$ fubu, $\sqrt{ }$ fubuennoù, ? plant, $\sqrt{ }$ plantennoù $\}$ a zo holl bihan-tout. the midges plants $\mathrm{R}$ is all small-very The midges/plants are all very small.

(23) \{An dud, Ar razhed, * Ar vandennad, * Ar familh $\}$ a zo holl bihan-tout. the people the rats the group the family $\mathrm{R}$ is all small-very [M1]

Candidates for floating each, pep 'each', pep a hini 'each of one', have the same profile:

(24) $\operatorname{Ar}\{\sqrt{ }$ fubu(ennoù), $\sqrt{ }$ plant(ennoù) $\}$ a zo pep ur c'hwezh ispisial dezho. the midges plants $\mathrm{R}$ is each a smell special of.them The midges/plants each have a special smell.

(25) \{ an dud, ar razhed, an arrebeuri, * ar vandennad logod, *ar familh \} the people the rats the furniture the group mice the family ... a zo pep a hini ur c'hwezh ispisial ganto. $\mathrm{R}$ is each of one a smell special with.them

\subsection{Diving quantifiers}

Floating quantifiers need to be strictly distinguished from look-alikes in lower position like binominal each; of these there is a variety, and we shall simply call them diving quantifiers. An illustration of their distinctiveness is the possibility and phi-features of dependent pronouns:

(26) Les filles avaient $\left({ }_{1}\right.$ chacune $\left.e_{\mathrm{i}}\right)$ amené $\left({ }_{2}\right.$ chacune $\left._{\mathrm{m}}\right)$ leur $\mathrm{i}_{\mathrm{i} / \mathrm{m} / \mathrm{n}}$ propre $/ \mathrm{sa}_{*_{\mathrm{i}} / \mathrm{m} / *^{*} \mathrm{n}}$ propre / une $\mathrm{i}_{\mathrm{i} / \mathrm{m} / \mathrm{n}}$ tente $\left({ }_{3}\right.$ chacune $\left._{\mathrm{n}}\right)$.

The girls had $\left({ }_{1}\right.$ each $\left.{ }_{\mathrm{i}}\right)$ brought $\left({ }_{2}\right.$ each) $\left\{\right.$ their $_{\mathrm{i} / \mathrm{m} / \mathrm{n}}$ own, her ${ }_{*_{\mathrm{i} / \mathrm{m} / *_{\mathrm{n}}}}$ own, $\mathrm{a}_{\mathrm{i} / \mathrm{m} / \mathrm{n}}$ tent $\}$ $\left(3\right.$ each $\left._{\mathrm{n}}\right)$.

Diving quantifiers have the potential to combine with group antecedents, putting each atomic members of a group in correspondence with (say) a tent, so they must be able to access the atoms somehow, say semantically by the membership function $f$. Yet they do not seem to be able to combine with object mass nouns, either because there are no atoms reachable by $\leq$ or $f$, or for some other reason.

(27) La troupe des filles avait ( ${ }_{1}^{*}$ chacune) amené ( 2 chacune) une tente ( ${ }_{3}$ chacune). The troop of the girls had ( ${ }_{1}$ each) brought $\left({ }_{2}\right.$ each $)$ a tent $\left({ }_{3}\right.$ each).

(28) Le courier a (*chacun) un/son/leur timbre (*chacun).

The mail has (*each) a/its/their stamp (*each).

In Breton, the quantifier pep $a+\mathrm{DP}$, lit. 'each of' + DP, is an adnominal quantifier that must combine with the DP, possibly an indefinite, to which it distributes its antecedent. It seems comparable to English binominal each (q.v. Stowell 2013) or better to French chacun that can combine with the DP within the PP Elles sont venues avec chacun un/son/leur sac 'They came with each a/her/their sac' (cf. Grevisse 2008: 8748). Breton pep $a$ is fine with regular and irregular plurals, with plurals of singulatives based on collectives, and with collectives themselves. For 
groups, we have mixed results. Like floating quantifiers, pep $a$ is good with 'furniture'.

(29) $\operatorname{Ar}\{\sqrt{ }$ fubu(ennoù), $\sqrt{ }$ plant(ennoù $)\}$ zo bet lonket gant pep a labous. the midges plants is been swallowed by each of bird The midges/plants were swallowed by a bird each.

[M3]

(30) Ar fubu(ennoù) neus kanet pep a damm barzhoneg. the midges has sang each of piece poem The midges sang each a little poem.

(31) \{ar razhed, al logod, *ar vandennad logod\} neus drebet pep a damm keuz. the rats the mice the group mice has eaten each of piece cheese

(32) \{an dud, ar familh \} neus lennet pep a damm barzhoneg. the people the family has read each of piece poem Each one/member of the family read each a poem.

(33) An arrebeuri neus bet pep a lufr koar. the furniture has had each of polish wax Each piece of furniture has been waxed.

\subsection{Adjunct quantifiers}

Quite different from floating and diving quantifiers in both position and restrictions on antecedents is one by one and counterparts with other cardinals. Unlike each, it can relate to arguments below it, be left- or righ-peripheral to the minimal clause containing the argument, and operate on the plurality over which a singular quantifier ranges. These generalisations are discussed and analysed in Brasoveanu and Henderson (2009), who contrast it with floating each in being able to apply to groups; probably, it is good with object mass nouns as well.

(34) (One by one) she called the players/police/cattle in (one by one)

(One by one) she called the players/police/cattle in (one by one)

(One by one) she called each player in (?one by one)

(One by one) she called the team in (one by one)

(One by one) she opened the morning's mail (one by one).

Brasoveanu and Henderson, very roughly, analyse one by one as an adjunct that cumlates the individuals that satisfy a theta-role in the event that satisfies the predicate's clause, makes sure there is a separate subevent for each atom in the resulting sum, and orders the events linearly. It is the cumulation step that renders the members of groups visible, and without spelling out how in the present theory of numerosity, we will see below that entailments about theta-role satisfiers access the members of a group.

For Breton, there are different possibilities for adjunct quantifiers, including unan hag unan 'one and one', a hini-enn-ou 'of one-SINGULATIVE-PL'. Tentatively, they are good with all manner of pluralities, with collectives, with groups though family resisted, and with 
object mass nouns. ${ }^{10}$

(35) $\operatorname{Ar}\{$ fubu(ennoù), plant(ennoù) $\}$ zo aet kuit unan a unan. the midges plants is gone away one of one The midges/plants went away one by one.

(36) \{an dud, ar razhed, al logod, ar vandennad logod, *ar familh\} the people the rats the mice the group mice the family ...zo aet kuit unan a unan.

is gone away one of one

(37) An arrebeuri neus steuziet unan a unan. the furniture has disappeared one of one The pieces of furniture disappeared one by one

(38) Ar beorien a oa aet kuit \{ a hiniennou / unan a unan \}. the poors $\mathrm{R}$ was gone away of one.SG.PL / one of one The poors left the one after the others.

\subsection{Phrasal reciprocals}

Phrasal reciprocals may now be treated very briefly, because empirically they give results very close to floating quantifiers, and theoretically may be assimilated to how these distribute into their antecedents: indeed, one way to think of The guests were talking to each other is as close to The guests were each talking to other guests (Heim, Lasnik and May 1991, Magri 2012). However, phrasal reciprocals are easy-going about antecedents:

(39) John came to the police station and claims that $\{$ the/most/some police officers, they ${ }_{\text {arb }}$, the police $\}$ were shooting at each other.

Thus it is more revealing that phrasal reciprocals in English and French are largely incompatible groups and object masses. Minimal contrasts can often be constructed with lexically reciprocal predicates like fight, kiss, and in French their clitic counterparts discussed below: ${ }^{11}$

(40) *The jury/furniture \{ressembles, is leaning against \} each other.

Whenever infantry/this team fights? (*each other), the hospital is full.

10. But see Acquaviva (2008: 262) reporting an irregular plural incompatible with a hiniennou, a result we could not reproduce.

11. English each other does vary quite a bit with groups, even singular-agreeing ones, in different sources in the literature; in French the results are far more categorial, so it is likely something about English groups. 
In Breton, the phrasal reciprocal varies somewhat across dialects, typical being an eil ... an egile/eben 'the second ... the second', an eil ... ar re all 'the second ... the others'. Regular and irregular plurals are fine as antecedents, as are plurals of singulatives from collectives. Collectives themselves are good too. The underived and derived groups we have tested are not good. However, the 'furniture' object mass noun is again good.

(41) $\operatorname{Ar}\{$ fubu(ennoù), plant(ennoù) $\}$ a zo o tont an eil war-lerc'h ar re all. the midges plants $\mathrm{R}$ is at come the second on-follow the ones other The midges/plants are coming the one after the other.

[M3]

(42) \{an dud, ar razhed, al logod, *ar vandennad, *ar familh\} the people the rats the mice the group the family

(43) ... a zeu an eil war-lerc'h $\{$ eben / egile \}. $\mathrm{R}$ comes the second after other.F/other.M

(44) Arrebeuri IKEA a dorr $\{$ an eil war-lerc'h egile/ar re all $\}$. furniture IKEA R breaks the second after other.M/the ones other Furniture IKEA breaks one piece after the other.

\subsection{Essentially distributive predicates}

We can give a very short shift to predicates like be similar, be neighbours, because they behave like phrasal reciprocals when plugged into the foregoing examples, and have been reduced to them, being close to be similar to each other, be each other's neighbours (Hackl 2002). In Breton too, heñvel 'similar' shows the same pattern as phrasal reciprocals. A caveat in testing is to first establish what an essentially distributive predicate is: in English, The jury is (too) similar cannot compare the members, but The jury looks alike or behaves similarly can and is merely a collective predicate, discussed below.

(45) Ar fubu(ennoù) amañ a zo heñvel. the midges here $\mathrm{R}$ is similar The midges here are similar (to each other).

(46) $\{$ an dud, ar razhed, al logod, * ar familh \} (amañ ) a zo heñvel-tout.

(47) the people the rats the mice the family here $\mathrm{R}$ is similar-all [M1]

(48) * Ar vandennad a zo (holl) heñvel. the group $\mathrm{R}$ is all similar [Ml]

(49) Er skol, evit ar vugale, an arrebeuri a zo heñvel-tout. at school for the children the furniture $\mathrm{R}$ is silimar-all At school the children have the same furniture. 


\subsection{Clitic reciprocity}

We can contrast phrasal reciprocity with clitic reciprocity. French has both phrasal reciprocals corresponding to English each other, and reciprocals formed with the reflexivereciprocal clitic se. The conditions on clitic reciprocity are known to be weaker than those on phrasal reciprocity: Les soldats se sont frappés (les uns les autres) 'The soldiers SE have struck (each other)' would omit the phrasal reciprocal in a «general mêlée» where only some soldiers participated or in a mixed reflexive-reciprocal scenario (cf. Cable 2013). Beyond pluralities, there is little known to us and we are hesistant. Certainly, some groups (perhaps especially animate ones) are fine with some clitic reciprocals, but quite difficult with others regardless of contexts (according to reflective grammaticality judgments; usage might well be a different matter). Object-mass nouns are similarly unclear. English translations with corresponding lexical reciprocals like fight, kiss, touch seem to be good and bad when French, but perhaps better on the $(*)$ examples. Theoretically, we have little to say here, but still send the reader to whatever we say about distributive predicates and about count.

(50) Les gymnastes \{se battent, se poussent, s'embrassent, se frappent, se touchent\} (*)Le groupe/famille/équipe se suit dans le noir.

L'équipe des gymnastes \{s'embrasse, $(*)$ se bat, *se pousse $\}$ encore. Linfanterie (*des...) \{s'embrasse, $\left({ }^{*}\right)$ se bat, ${ }^{*}$ se pousse $\}$ encore. ${ }^{12}$

(*)La famille d'à côte est en train de se battre.

Quand je suis rentré à la maison, notre nouveau mobilier robotique se battait! $\left\{{ }^{*}\right.$ Le bouquet, ${ }^{*}$ La collection, Léquipe des gymnastes\} des fleurs se touche. ${ }^{13}$

Il faut que \{la vaisselle, le courier, l'argent\} ne se touche pas.

!Il y a \{de la vaisselle, de l'infanterie\} qui se touche. ${ }^{14}$

In Breton, we have only tested Breton en em heuliañ, French se suivre, 'follow each other'. It is good with all pluralities, with collectives, and with groups.

(51) En em heuliañ a ra ar $\{$ fubu(ennoù), plant(ennoù)\}. reflexive follow $\mathrm{R}$ does the midges plants The midges/plants follow each other.

(52) En em heuliañ a ra \{an dud, ar razhed, ar vandennad logod, ar familh\}. reflexive follow $\mathrm{R}$ does the people the rats the group mice the family [M1]

12. French infanterie seems to be mass, given de l'infanterie and the unavailability of the grouppartitive.

13. Here se toucher is fine as reflexive, not reciprocal; see under distributive predicates.

14. Here unlike in the negative de seems to force a strictly substance use, odd with vaisselle and pejorative with infantry. 


\subsection{Collective, distributive, and stubbornly distributive predicates}

Collective predicates need a complex argument of some sort, but let it be pluralities, groups, and all sorts of mass nouns: gathered around the hillock may hold of members of the jury, the jury, infantry, mail, water, gravel, pile of wood, perhaps having all their denotations in its domain. Distributive predicates like yawn, be born in Tsetserleg, be underweight feel like they need to hold of a person individually, and at any rate give rise to entailments where they do so, and use with arguments other than (pure) atoms requires a way of looking inside. This is possible if often marked with pluralities, and to some extent with groups and object masses: The jury/infantry yawned; My family was born in Tsetserleg. Mixed predicates apply both to atoms and certain complex individuals. In These players/boxes is too heavy, the predicate can hold of all the boxes together, for the weigt limits of an elevator, or individually, to be transported by our donkeys. With groups and object mass nouns like this pile/furniture instead of the subject, use for the whole is good, but use for the constituents can be found, though is harder and subject to considerable variation. Champollion (to appear) reviews distributivity and collectivity.

One way to think about all these predicates is that they are all indiscriminate about what is in their denotation, but do not make sense with particular individuals: gather makes no sense with atoms (i.e. pure atoms), something that seems essential, and be underweight happens not to make sense with anything except atoms, though that seems conventional. This view naturally leads to subtleties: assemble differs from gather on substances, The water assembled, presumably by implications about the structure of its argument; old is like heavy in on groups, so that The team is old can measure the lifetime of the team or its members, but unlike heavy, it holds only of the atoms of a plurality and not the whole, The players are old, presumaby because there is no such thing as the lifetime of a plurality. If this «looking inside» is needed by lexical semantics, the appropriate relations are available in $\leq_{c}, \leq_{m}$, and $f$, but the boundary between lexical entailments and pragmatic inference is unclear to us. We are left with a number of mysteries for this view, e.g. The committee got to its feet \#and scratched its head(s). (See e.g. Dowty 1986, Barker 1992).

Of particular importance recently have been stubbornly distributive predicates like be round, small, tall (Schwarzschild 2011). They hold of atoms like the box, and of the atoms of a plurality like the boxes, but no of the whole: The boxes are small cannot be true if each box is large but they are few and so together take up little space, unlike The pile of boxes is small. Their interest dervies from how they treat mass nouns: for object masses that intuitively have clear minimal pieces, like furniture, ammunition, infantry, they hold of those pieces only, even when that leads to little sense, \#Infantry is round, while with other object masses they are simply out, \#Snow is small. ${ }^{15}$ Schwarzschild raises the possibility that they are predictes that have only atoms in their denotation, and so like be underweight of our discussion, but for reasons intuitively less clear; if object passes are pluralities, their behavior would follow. We are not sure what to say about behavior with groups, This group of boxes is small, for they seem to be able to hold of the group only (which is fine), and not of its members (and we do not see why, given be old, underweight, which

15. Apparently one can package it: «Snow is smaller than I thought» looking at one's first snowflakes (U. K. Le Guin, Planet of Exile). 
perhaps resist but not at all like be small). ${ }^{16}$

In Breton, we have seen clitic reciprocals already, which generally seem to be have like collective predicates. Otherwise, the stubbornly distributive predicate bihan 'small' behaves as expected: with all pluralities it must hold of the atoms, and likewise with the object mass noun 'furniture', but only of the whole with groups. Collectives behave like the former and not the latter.

(53) Bihan eo $\{$ ar fubu(ennoù) $/ *$ an dour $\}$.

small is the midges(SG.PL) / the water

The midges are small, \# There are few midges. ${ }^{17}$

(54) Bihan(-tout) eo \{ an dud, ar razhed, al logod, an arrebeuri $\}.$ small-very is the people the rats the mice the furniture

(55) $\{$ Bihan-tout $/ *$ lart $/ *$ tev $\}$ eo $\{$ ar familh / ar vandennad $\}$

small-very fat fat is the family the group

The \{family / the group $\}$ is small.

*The members of the $\{$ family /group\} are small.

\subsection{Cardinality, adnominal}

Adnominal cardinals (five, fifty) and vaguer cardinality expressions (many, few) combine only with count nouns, and cannot look inside groups: five/many *jury/ juries/*furniture/*furnitures. Cardinals and vaguer cardinality expresions part ways with lexical plurals close to the mass border, like police, cattle. Cardinals are bad, though less so for large rounded-off ones, while many/few are better. The noun must be treated as a plural by agreement and not singular as it sometimes can be otherwise. ${ }^{18}$

(56) This spring, ?five/two hundred/many cattle have been innoculated against rabies. This spring, ?five/two hundred/many cattle have been innoculated against rabies. *Five/?(?)Many clothes are still dirty.

There are still *five/?(?)many groceries left in the trunk.

You play this game with oats? And?*five/??how many oats are needed?

16. Schwarzschild argues for a different account that the option considered because the one in the text leaves unclear what to do about masses like snow, and on a particular view of groups, their behavior here makes more sense. Very roughly indeed, singular count nous hold of one pure atom per event, pluralised of multiple, object mass nouns of either, substance mass nouns of multiple, and stubbornly distributive predicates of one only; groups would then hold of one group atom in an event, but whenever they have multiple members, of several members.

17. The speaker reports familiarity with the meaning 'There isn't a lot of midges' for the collective Bihan eo ar fubu, but does not have it herself.

18. There is a great deal of speaker variation in this domain; for example judgments see McCawley (1975), Allan (1980), Acquaviva (2008). 
There are * five/??too many news under each heading.

*Five/\%Many waters will cover Tyre.

Harking back to our discussion of floating quantifiers, cattle seems to differ from cows in the «salience» of the individual cows in it, and the precisely-counting cardinals seem to that salience more than than the vaguer many/few. How to get to this is another matter. Thinking of Chierchia (1998ab), sketched earlier, cardinals would rely on there being a predicate that holds only of the atoms of what is to be counted, and while for cows there is cow, for cattle (with bulls and all) there is none. This would have to be finessed to explain why counting cattle is easier than counting police, why counting people is perfect, and counting furniture is impossible. ${ }^{19}$ Otherwise, see Brisson (2003), Chierchia (2010) on the role of context in defining atoms; Krifka (2007), Rothstein (2010) on how particular nouns might supply ways of counting; and Lasersohn (2011), Winter an Scha (2014) on the semantics of cardinality expressions.

There is a great deal of variation in the construction in which count nouns combine with cardinals and counting quantifiers. In Breton, cardinals with count nouns take the singular always. With other categories, we have telling but mysterious behavior. Collectives cannot be counted, but neither can singulatives formed from them that look like count singulars, nor the plurals of these. The members of a group cannot be counted with a group noun, which is expected, but our derived group noun in -ad fails to combine with a cardinal entirely. Quite unexpectedly, the pieces of the object-mass noun 'furniture' can be counted just fine, though they can also be counted by means of a classifier in the type piece of furniture, which attests to its really being a mass noun (cf. pieces of (the) chairs $\neq$ chairs).

(57) Pemp $\{*$ fubu(ennoù), * plant(ennoù) $\}$ a oa aze.

five midges plants $\mathrm{R}$ is here

(58) Pemp \{razh, logodenn, * razhed, * bandennad\} a oa aze. five rat mouse rats group $\mathrm{R}$ was here

(59) Pemp (penn/pezh) arrebeuri a oa aze. five head/piece furniture $\mathrm{R}$ was here

The vaguer cardinality expression pet is like how many in combining with count and not mass nouns; like cardinals it combines with the singular of a count noun. The results with collectives are most interesting: as expected, pet can combine with the singular of a singulative drived from a collective but not with the plural thereof, but remarkably it can combine with

19. This does not seem to us a hopeless task; with people, usage is intricate, but it seems possible that people is an allomorphic plural of person on some meanings, while persons is the plural on others (e.g. with legal or philosophical comitments); cattle is closer to cow than furniture is to $\ldots$ to any predicate that describes its pieces, chair, table, .... 
a collective to count its constituents. Like cardinals, it cannot combine with a singular group to count its members. Again, goodness with 'furniture' is unexpected, or rather expected after the behavior of cardinals.

(60) Pet $\quad\left\{\sqrt{ }\right.$ fubu, ${ }^{*}$ fubuennoù, $\sqrt{ }$ plant, ${ }^{*}$ plantennoù $\}$ t'eus gwelet? how.many midges /plants you'have seen

How many midges/plants have you seen?

(61) Pet \{razh, logodenn, * razhed, * bandennad\} t'eus gwelet? how.many rat mouse rats group you.have seen [M1]

(62) Pet arrebeuri t'eus roet da Emmaüs, a-benn ar fin? how.many furniture you.have given to Emmaüs at the end How many pieces of furniture did you give to Emmaus at the end?

Other expressions quantify the amounts of both count and mass nouns, such as lots of. In Breton, we have looked at the post-nominal element $e$-leizh 'lots of'. It measures whatever is inside a plurality, a singular group, a mass noun of any sort, a collective and the plural of its singulative, excluding only singular count nouns where there is nothing to measure inside. ${ }^{20}$

(63) $\{$ tud $/ *$ den $\}$ e-leizh, people/person a-lot a lot of people, a lot of water

\section{dour e-leizh}

water a-lot

Standard

(64) Ar stered zo leizh anezhe.

the stars is a-lot of.them

There is a lot of stars.

(65) Bez' zo $\{\sqrt{ }$ fubu, $\sqrt{ }$ fubuennoù, ? $/ \sqrt{ }$ plant, $\sqrt{ }$ plantennoù $\}$ e-leizh.

expl is midges / plants a-lot

There is a lot of midges/plants.

(66) Bez' zo \{tud, familh\} e-leizh.

expl is people family a-lot

There is a lot of people/family members.

\subsection{Counting}

In contrast to other counting words, the predicate count is very liberal: one can count plural count nouns like fruits, coins, soldiers, members of groups like jury, family but not others like col-

20. Hesitation on plant is due to a competing count singular meaning 'a plant', as in French. 
lection, pile with perhaps animacy effects in counting the group of ?\%girls/* chairs, the constituents of an object mass argent/money, change, furniture, silverware, ?clothing, ammunition, vaisselle, ?infanterie, and to some extent granular substances like corn if units like kernels or (much better) cobs are salient enough, as well as some nouns at frontier between lexical plurals and mass nouns, police, betail, cattle, clothes, groceries, \%oats, \%embers, \%furnishings, *dregs. We have no theory of other than what we have said about predicates looking inside groups and object passes earlier.

In Breton, count can count inside all manner of plurals and not count singulars, and the object mass furniture, but not the groups we have tested. With collectives, we have some good results, some bad ones.

(67) Start eo kontañ ar $\{\sqrt{ }$ fubu(ennoù $), *$ plant, $\sqrt{ }$ plantennoù $\}$.

hard is count the midges plants

It is hard to count the midges/plant.

(68) Start eo kontañ $\{*$ ar razh, ?/* ar vandennad logod /* ar familh $\}$.

hard is count the rat the group mice the family

It is hard to count the rat/group of mice/family.

(69) Start eo kontañ $\{$ an dud, ar razhed, an arrebeuri $\}$

hard is count the people the rats the furniture

It is hard to count the people/rats/pieces of furniture.

\subsection{Cardinality, Predicate}

Cardinality expressions also occur as predicates, be twenty/many. They impose a referentiality restriction on their subject similar to that of floating quantifiers (Solt 2009, Lasersohn 2011). Otherwise, they seem to present a weaker version of the patterns of their adnominal counterparts: they combine with count plurals, less so lexical plurals, less so groups, and not at all object masses. The predicate be numerous and its French counterpart seem similar in limitation to referential antecedents, but a great deal more sharp-eyed:

(70) $\{$ The, *All, *Most, *Some $\}$ protesters are $\{$ few but determined, twenty in number, too numerous to dismiss\}.

The cattle/?police were ffew but determined, ?seven in number, too numerous to stop\} when they broke in.

The team/infantry is $\left\{?^{*}\right.$ few but determined, *twenty in number, ?\% too numerous\}.

The mail is $\{*$ too many to keep track of, *twenty in number\}.

The mail is $\left\{{ }^{*}\right.$ too many to keep track of, ?\%too numerous for one person to handle\}.

The furniture is numerous and varied. (Cowper and Hall 2012)

(*)La vaisselle / (*)Le courier est trop nombreux.

In Breton, we have only looked at niverus 'numerous'. It can apply to plural and not singular count nouns; there is variation on group nouns; and it is good with the object mass 
furniture..$^{21}$

(71) Niverus eo $\operatorname{ar}\{\sqrt{ }$ fubu, * fubuennoù, * plant, $\sqrt{ }$ plantennoù $\}$ amañ. numerous is the midges plants here The midges/plants are numerous here.

(72) Niverus eo $\left\{{ }^{*}\right.$ ar razh, * ar vandennad logod $\}$. numerous is the rat the group mice

(73) Niverus eo \{ an dud, ar razhed, al logod, ar familh, an arrebeurri\} amañ. numerous is the people the rats the mice the family the furniture here [M1]

\subsection{Partitives}

The members of a group may be specified by the group-partitive of + a bare, cardinal, or definite plurality, this committee of $\{$ the, three, * most, Æ girls\}, this book of matches. Barker (1992) gives of the semantics in (x), which requires that any atom that committee holds of be mapped by $f$ to the denotation of the complement of of. ${ }^{22}$ Of cannot function in this manner with object mass nouns, the infantry of the dwarves being only partitive, or nof pluralities, the footsoldiers of the dwarves, treating them the same, as they are also on the other side of of, this group of our infantry/footsoldiers (cf. Gillon 2012).

$$
\|o f\|=\lambda y_{e} \cdot \lambda p_{e t} \cdot \lambda x_{e} \cdot Q(x) \& f(x) \leq y
$$

Similarly, we could look at measuring out a mass, a piece of fruit $\left({ }^{*} \mathrm{~s}\right)$, partitive restrictions of quantifiers, three of the group of girls/*chairs, and so on (cf. Pearson 2011).

In Breton, there are different constructions translating of phrases: the construct state like (*ar) c'harrad ar mein-se '(*the) cartful of stones-this', adjectival apposition ar c'harrad mein 'the cartful of stones', and prepositions, an dud a vor 'the folk of sea' (Kervella 1947: $\S \$ 358 f f$., Favereau 1997:\$100ff.). We have looked only at adjectival apposition, and that most preliminarily. The constituency of a group noun can be specified by both plural singulative and its collective basis. A piece type classifier cannot combine with either a plural singulative or its collective base. A kilo type measure phrase differentiates the collective, with which it is fine, from its plural singulative. A half type partitive cannot combine with either. We must defer interpretation of these results until we can compare them with other expressions.

(75) Bihan-tout eo ar vandennad $\{\sqrt{ }$ fubu, ? fubuennoù $\}$.

21. In the dialect of this particular speaker, postverbal plural subject permit plural agreement to some extent; it is of interest that an arrebeuri 'the furniture' refuses it, showing it is not simply a plurality.

22. On the assumption that (the traces of) three/ $\varnothing$ girls denote individuals. 
small-very is the group midges

The group of midges is very small.

[M3]

(76)

ur strollad $\{$ ? fubu, fubuennoù, $\sqrt{ }$ plant(ennoù) $\}$

a group midges plants

[M3]

(77) ul lodenn $\quad\left\{{ }^{*}\right.$ fubu(ennoù), ${ }^{*}$ plant(ennoù) $\}$

a piece.SG midges plants

(78) $\operatorname{urc}$ c'hilo $\{\sqrt{ }$ fubu, $\underset{*}{*}$ fubuennoù, $\sqrt{ }$ plant, $\underset{*}{-}$ plantennoù $\}$

a kilo midges plants

(79) un hanterenn * plant(ennoù).

a half plants

\section{Conclusion}

This pilot study of course is only a first step toward studying numerosity and number in Breton. The sole speaker with who we were able to test the tripartite collective - singulative singulative plural distinction is a prototypical young native speaker of the twenty-first century. $\mathrm{M}$ was raised in a bilingually family and environment, by fluent but non-native parents, with nativespeaker siblings with whom she exchanged almost entirely in Breton prior to school, schooled in a monolingual Breton environment, and continuing with Breton uninterrumptedly throghout her personal and professional life despite sicialisation including French monolingual areas. Contrary to the idea that the sociolinguistic extremely minorized position of the language makes it unable to be tested on young speakers anymore, we found that her results were robust: (i) judgments consistent across sessions; (ii) sharp judgments on semantically borderline novel sentence types; (iii) lack of hypercorrection where her judgments diverged from standard Breton, and (iv) uncertainty in domains that correspond to those where there is uncertainty in English and French. It will be very interesting to see if further testing of older generations will provide a contrast or not, and its character.

Taking stock of the results on our diagnostics for $\mathrm{M}$, we have the following picture. The behavior of count singulars and count plurals is roughly as in English and French, and morphologically irregular plurals behave like regular ones, as does tud 'people', either a wholly irregular plural of den 'person' that lacks its own plural, or a plurale tantum. Group nouns likewise are comparable to group nouns in English and French, setting aside the plural-agreeing group nouns in English. We have found some variation, which needs study in light of known differences in English between family, class, grove, collection...

Of collectives and the plurals of their singulatives, focusing on fubu 'midges', we find that they are both essentially like count plurals, differing only on behavior with pet 'how many' (grey box in the Appendix), where the collective is like a count plural and the singulative is not. Yet lest one be tempted to suppose that M's linguistic background has eroded distinctions present for older speakers, $\mathrm{M}$ too reports the perception that the plural of a singulative is different from both a collective and a regular count plural: perennoù 'pears', plural singulative, is more appropriate than per 'pears' for what goes into baking a single pear tart, and that in perennoù 
the individual pears are somehow more salient than in per. Putative erosion must be carefully substantiated. Breton like English distinguishes pet 'how many' and pegement 'how much', and French does not; M's grammar has been unaffected on this point. French's influence is visible specifically in borrowings: originally collective plant 'plants' has had its behaviour troubled by borrowing of count plant 'plant'. ${ }^{23}$

So a prudent conclusion at this point seems to us to be that our tests are not fine enough or applied finely enough to discern the nature of the perceived distinctions between count plurals, collectives, and their singulative plurals, save to the extent that pet hints at possibilities. On a first try, this is unsurprising: the formal differences on our tests between people, cattle, police, oats are few, subtle, and subject to much variation, and theoretically hard to interpret, while access to the intuition that cattle is somehow more vague in the salience of indiviual beasts is readily available. The same goes for lexical plurals: there are differences and similarities on our tests in the range from groceries to oats to wits to barrens, both clear and subtle, and correlated with introspectively accessible intuitions about their relationship to their parts, but hard to work out theoretically with the tools we have. There are likely to be differences outside the domain of our tests, say on homogeneity of form versus function or spatiotemporal contiguity (Acquaviva 2008, Henderson 2014; Lammert 2015, Lauwers 2014). However, these do not a priori tell us why groceries can be more reciprocal than oats. It is likely enough that the elementary theory of numerosity is inadequate, telling us nothing for instance in how individuals relate to events or minimal situations in which they satisfy their predicate (Schwarzschild 2011).

Beside collectives, sole object-mass noun we have looked at, arrebeuri 'furniture', turned out to be very suprising indeed. On the semantic test, it behaves consistentaly as a count plural. Yet it is not a count plural. It controls singular agreement, antecedes singular pronouns, and unlike count plurals participates in constructions like a piece of furniture (cf. *a piece of chairs). M's grammar offers another insight into the syntax and semantics of this item. In M's grammar, there has been an innovation whereby postverbal plural subjects allow though not require agreement. This is unusual across Breton varieties (Jouitteau and Rezac 2006, 2008, Jouitteau 2009-2015:'agreement'). This innovation is not an «erosion» of M's agreement system, as pre-negation subjects behave strictly as in standard Breton, requiring plural agreement when plural. The interesting point is that for $\mathrm{M}$, both preverbal and postverbal arrebeuri is strictly singular, as it is for anaphoric pronouns, like the singulars of both (pure) atom and group (atom) nouns.

(80) N' $\{$ eo / int $\}$ ket chalet al logod gant $\left\{{ }^{*} \mathbf{e}, \sqrt{ } \mathbf{o}\right\}$ fourmaj laezh! neg is/are not tormented the mice with his/their cheese milk The mice are happy with their cheese. (litt: The mice is ... with their...') [M3]

(81) Niverus int $\{$ ar razhed, an dud, *ar familh, * an arrebeurri\}. numerous are the rats the people the family the furniture

23. Cf. Favereau (1997) on borrowings of articho 'artichoke(s)', banan 'banana(s)' as both collectives and their singulatives. 
Methodologically, and taking stock of our first difficulties to identify collective triplets or any object-mass noun with older speakers, further investigation should proceed in two steps: a first session identifying lexical items pairing the tripartite opposition with robust plural anaphora; distinct session(s) applying semantic tests, coupled to detailed plausible contexts maximally fixing intended interpretations.

\section{Appendix}

\begin{tabular}{|c|c|c|c|c|c|c|c|}
\hline \multicolumn{2}{|l|}{ M. } & tud & razhed & fubu & fubuennoù & plant & plantennoù \\
\hline \multicolumn{2}{|c|}{ Verbal agreement } & PL & PL & PL & PL & PL & PL \\
\hline \multicolumn{2}{|c|}{ Pronominal reference } & PL & PL & PL & PL & PL & PL \\
\hline \multicolumn{2}{|c|}{ Floating quantifiers holl } & $\sqrt{ }$ & $\sqrt{ }$ & $\sqrt{ }$ & $\sqrt{ }$ & $?$ & $\sqrt{ }$ \\
\hline \multicolumn{2}{|c|}{ Floating quantifiers pep a } & $\sqrt{ }$ & $\sqrt{ }$ & $\sqrt{ }$ & $\sqrt{ }$ & $\sqrt{ }$ & $\sqrt{ }$ \\
\hline \multicolumn{2}{|c|}{ Diving quantifiers } & $\sqrt{ }$ & $\sqrt{ }$ & $\sqrt{ }$ & $\sqrt{ }$ & $\sqrt{ }$ & $\sqrt{ }$ \\
\hline \multicolumn{2}{|c|}{$\begin{array}{l}\text { Adjuncti quantifiers unan } \\
\text { a unan }\end{array}$} & $\sqrt{ }$ & $\sqrt{ }$ & $\sqrt{ }$ & $\sqrt{ }$ & $\sqrt{ }$ & $\sqrt{ }$ \\
\hline \multicolumn{2}{|c|}{ Phrasal reciprocals } & $\sqrt{ }$ & $\sqrt{ }$ & $\sqrt{ }$ & $\sqrt{ }$ & $\sqrt{ }$ & $\sqrt{ }$ \\
\hline \multicolumn{2}{|c|}{$\begin{array}{l}\text { Essentially distributive } \\
\text { predicates heñvel }\end{array}$} & $\sqrt{ }$ & $\sqrt{ }$ & $\sqrt{ }$ & $\sqrt{ }$ & & \\
\hline \multicolumn{2}{|c|}{ Clitic reciprocity } & $\sqrt{ }$ & $\sqrt{ }$ & $\sqrt{ }$ & $\sqrt{ }$ & $\sqrt{ }$ & $\sqrt{ }$ \\
\hline \multicolumn{2}{|c|}{$\begin{array}{l}\text { Stubbornly Distributive } \\
\text { predicates }\end{array}$} & $\sqrt{ }$ & $\sqrt{ }$ & $\sqrt{ }$ & $\sqrt{ }$ & & \\
\hline \multirow{3}{*}{$\begin{array}{l}\text { Cardinality, } \\
\text { adnominal }\end{array}$} & 5 & & * & $*$ & * & * & * \\
\hline & pet & & $*$ & $\sqrt{ }$ & $*$ & $\sqrt{ }$ & * \\
\hline & e-leizh & $\sqrt{ }$ & $\sqrt{ }$ & $\sqrt{ }$ & $? / \sqrt{ }$ & $\sqrt{ }$ & \\
\hline \multicolumn{2}{|l|}{ Counting } & $\sqrt{ }$ & $\sqrt{ }$ & $\sqrt{ }$ & $\sqrt{ }$ & $*$ & $\sqrt{ }$ \\
\hline \multicolumn{2}{|c|}{$\begin{array}{l}\text { Cardinality, predicate } \\
\text { niverus }\end{array}$} & $\sqrt{ }$ & $\sqrt{ }$ & $\sqrt{ }$ & $*$ & * & $\sqrt{ }$ \\
\hline \multirow{5}{*}{ Partitives } & bandennad & & $\sqrt{ }$ & $?$ & & & \\
\hline & strollad & & $?$ & $\sqrt{ }$ & $\sqrt{ }$ & $\sqrt{ }$ & \\
\hline & lodenn & & * & * & * & * & \\
\hline & kilo & & $\sqrt{ }$ & * & $\sqrt{ }$ & * & \\
\hline & hanterenn & & & & * & $*$ & \\
\hline
\end{tabular}

\begin{tabular}{|l|l|l|l|l|l|l|}
\hline M. & logod & bandennad & familh & arrebeurri & razh & \\
\hline
\end{tabular}




\begin{tabular}{|c|c|c|c|c|c|c|c|}
\hline \multicolumn{2}{|c|}{ Verbal agreement } & PL & SG & SG & SG & SG & SG \\
\hline \multicolumn{2}{|c|}{ Pronominal reference } & PL & & & & SG & SG \\
\hline \multicolumn{2}{|c|}{$\begin{array}{l}\text { Floating quantifiers } \\
\text { holl }\end{array}$} & & $*$ & $*$ & & & \\
\hline \multicolumn{2}{|c|}{$\begin{array}{l}\text { Floating quantifiers } \\
\text { pep a }\end{array}$} & & $*$ & $*$ & $\sqrt{ }$ & & \\
\hline \multicolumn{2}{|c|}{ Diving quantifiers } & $\sqrt{ }$ & $*$ & $\sqrt{ }$ & $\sqrt{ }$ & & \\
\hline \multicolumn{2}{|c|}{$\begin{array}{l}\text { Adjunct quantifiers } \\
\text { unan a unan }\end{array}$} & $\sqrt{ }$ & $\sqrt{ }$ & $*$ & $\sqrt{ }$ & & \\
\hline \multicolumn{2}{|c|}{ Phrasal reciprocals } & $\sqrt{ }$ & $*$ & $*$ & $\sqrt{ }$ & & \\
\hline \multicolumn{2}{|c|}{$\begin{array}{l}\text { Essentially } \\
\text { distributive predicates } \\
\text { heñvel }\end{array}$} & $\sqrt{ }$ & * & * & $\sqrt{ }$ & & \\
\hline \multicolumn{2}{|c|}{ Clitic reciprocity } & & $\sqrt{ }$ & $\sqrt{ }$ & & & \\
\hline \multicolumn{2}{|c|}{$\begin{array}{l}\text { Stubbornly } \\
\text { distributive predicates }\end{array}$} & $\sqrt{ }$ & * & * & $\sqrt{ }$ & & $*$ \\
\hline \multirow{3}{*}{$\begin{array}{l}\text { Cardinality, } \\
\text { adnominal }\end{array}$} & 5 & & $*$ & & $\sqrt{ }$ & $\sqrt{ }$ & \\
\hline & pet & & $*$ & & $\sqrt{ }$ & $\sqrt{ }$ & \\
\hline & e-leizh & & & $\sqrt{ }$ & & & $\sqrt{ }$ \\
\hline \multicolumn{2}{|l|}{ Counting } & & $? / *$ & $*$ & $\sqrt{ }$ & $*$ & \\
\hline \multicolumn{2}{|c|}{$\begin{array}{l}\text { Cardinality, predicate } \\
\text { niverus }\end{array}$} & $\sqrt{ }$ & * & $\sqrt{ }$ & $\sqrt{ }$ & $*$ & \\
\hline
\end{tabular}

\section{References}

Acquaviva, Paolo. 2008. Lexical plurals. Oxford University Press: Oxford.

Allan, Keith. 2012. Pragmatics and the (English) lexicon. In The Cambridge handbook of pragmatics, ed. by Keith Allan and Kasia Jaszczolt, 227-250. Cambridge: Cambridge University Press.

Allan, Keith. 1980. Nouns and countability. Language 56: 541-567.

Anderson, Stephen R. 1986. Disjunctive Ordering in Disjunctive Morphology. Natural Language and Linguistic Theory 4: 1-31.

Barker, Chris. 1992. Group terms in English. Journal of Semantics 9: 69-93.

Barner, David, and Jesse Snedeker. 2005. Quantity judgments and individuation: evidence that mass nouns count. Cognition 97: 41-46. 
Brasoveanu, Adrian, and Robert Henderson. 2009. Varieties of distributivity: one by one vs. each. In Proceedings of SALT 19, 55-72. On-line:

http://journals.linguisticsociety.org/proceedings/index.php/SALT/

Brisson, C. 2003. Plural, all, and the non-uniformity of collective predication. Linguistics and Philosophy 26: 129-184.

Cable, Seth. 2014. Reflexives, reciprocals and contrast. Journal of Semantics 31: 1-41.

Caer, M. G. 1906. Essai de grammaire bretonne. Feiz ha Breiz 3.11: 331-4.

Champollion, Lucas. to appear. Distributivity, collectivity, and cumulativity. In Companion to Semantics, ed. by Lisa Mathewson. Wiley-Blackwell.

Chierchia, Gennaro. 1998a. Reference to kinds across languages. Natural Language Semantics 6: 339-405.

Chierchia, Gennaro. 1998b. Plurality of mass nouns and the notion of «semantic parameter». In Events and Grammar, ed. S. Rothstein, 53-103. Dordrecht: Kluwer.

Chierchia, Gennaro. 2010. Mass nouns, vagueness and semantic variation. Synthese 174: 99-149.

Cirillo, Robert. 2009. The syntax of floating quantifiers. Doctoral dissertation, University f Utrecht.

Corbett, Greville. 2004. Number. Cambridge: Cambridge University Press.

Cowper, Elizabeth, and Daniel Currie Hall. 2013. Aspects of individuation. In Count and mass across languages, ed. by Diane Massam. 2013, 27-53. Oxford: Oxford University Press.

Doetjes, Jenny. 2012. Count/mass distinctions across languages. In Semantics, ed. by Claudia Maienborn, Klaus von Heusinger and Paul Portner, 2559-2580. Berlin: De Gruyter.

Dowty, David 1986. Collective predicates, distributive predicates, and all. In ESCOL '86, 97-115. Columbus, Ohio: Ohio State University.

Elbourne, Paul. 1999. Some correlations between semantic plurality and quantifier scope. In Proceedings of NELS 29, 81-92. Amherst, Mass.: GLSA.

Elbourne, Paul. 2013. Definite descriptions, Oxford:Oxford University Press.

Favereau, Francis. 1997. Grammaire du breton contemporain, Morlaix: Skol Vreizh.

Fitzpatrick, Justin. 2006. The syntactic and semantic roots of floating quantification. Doctoral dissertation, MIT.

Gillon, Brendan. 2012. Mass terms. Philosophy Compass 7: 712-730.

Grevisse, Maurice, and André Goosse. 2008. Le bon usage. Bruxelles: De Boeck \& Larcier.

Gros, Jules. 1970. Le trésor du breton parlé II (Eléments de Stylistique Trégorroise). Dictionnaire breton-français des expressions figurées. Librairie Bretonne Giraudon.

Gros, Jules. 1974. Le trésor du breton parlé III. Le style populaire (Éléments de stylistique trégorroise). Barr-Heol, Lannion: Giraudon. [1984, Emgleo Breiz].

Hackl, Martin. 2002. The ingredients of essentially plural predicates. In Proceedings of NELS 32 , 171-182. Amherst, Mass.: GLSA.

Heim, Irene, Howard Lasnik, and Robert May. 1991. Reciprocity and plurality. Linguistic Inquiry 22: 63-101.

Henderson, Robert. 2014. Swarms: Spatiotemporal grouping across domains. Ms., Wayne State University.

Henry, Jean-Louis. 1906. Ar gwenan, penos tenna diganto o mel heb o distruja. Karaez: Moullerez 
Dre-Dan ar Bobl.

Hoeksema, Jacob. 1996. Floating quantifiers, partitives and distributivity. In Partitives, ed. by Jacob Hoeksema, 57-106. Berlin: Mouton de Gruyter.

Huddlestone, Rodney, and Geoffrey K. Pullum. 2002. The Cambridge grammar of the English language. Cambridge: Cambridge University Press.

Irslinger, Britta. 2014. The gender of abstract noun suffixes in the Brittonic languages. Sergio Neri $\&$ Roland Schumann (éds.), Studies on collectives and feminine in Indo-European languages, Leiden/Boston Brill: 57-113.

Jouitteau, Mélanie and Milan Rezac 2006. Deriving the Complementarity Effect. Lingua 116: 19151945.

Jouitteau, Mélanie and Milan Rezac, 2008. From mihi est to have across Breton dialects. In Rivista di Grammatica Generativa 32: 161-178.

Jouitteau, Mélanie. 2009-2015. ARBRES, wikigrammar online of the dialects of the Breton language. http://arbres.iker.cnrs.fr.

Junker, Marie-Odile. 1995. Syntax et sémantique des quantifieurs flottants tous et chacun. Genève: Librarie Droz.

Kayne, Richard. 2010. Comparisons and contrasts. Oxford: Oxford University Press.

Kervella, Fransez, 1947. Yezhadur bras ar brezhoneg, 1947 édition Skridoù Breizh, La Baule. [1995, Al Liamm].

Krifka, Manfred. 2007. Masses and countables. Handout of a presentation at CASTL workshop «The syntax and semantics of measurement», University of Tromso, September 17-18, 2007.

Lammert, Marie. 2015. Les pluralia tantum sous l'angle du collectif. Langue française 185: 73-84.

Lasersohn, Peter. 2011. Mass nouns and plurals. In Semantics, ed. by Claudia Maienborn, Klaus von Heusinger and Paul Portner, vol. 2, 1131-1153. Berlin: de Gruyter.

Lauwers, Peter. 2014. Les pluriels «lexicaux». Langue française 183: 117-132.

Le Bayon, A.-M. 1878. Grammaire bretonne du dialecte de Vannes. Vannes: Imprimerie Lafolye. [1986, Hor Yezh]

Le Roux, Pierre. 1927. Atlas linguistique de la Basse-Bretagne, 4 vols. lieu: editeur

Link, Godehard. 1983. The logical analysis of plural and mass bouns. In Meaning, Use, and Interpretation of Language, ed. by R. Bäuerle et al., 302-323. Berlin: de Gruyter.

McCawley, James. 1975. Lexicography and the count-mass distinction. Proceedings of BLS 1, 314-21. Berkley, Calif.: Berkley Linguistics Society. On-line: http://escholarship.org/uc/ item/7cw560p2.

Magri, Giorgio. 2012. Collective nouns without groups. In IATL 27: Proceedings of the 27th annual meeting of the Israeli Association for Theoretical Linguistics, 183-202. Cambridge, Mass: MITWPL. On-line: http://www.iatl.org.il/.

Massam, Diane (ed.). 2013. Count and mass across languages. Oxford: Oxford University Press.

Menard, Martial, and Ywan Kadored. 2001. Geriadur Brezhoneg. Plougastell-Daoulas: An Here.

Merser, Andreo. 2011. Précis de grammaire bretonne, Emgleo Breiz.

Nicolas, David. 2012. The logic of mass expressions. Stanford Encyclopedia of Philosophy. On-line: http//plato.stanford.edu. 
Nouwen, Rick. 2015. Plurality. In The Cambridge handbook of semantics, ed. by Paul Dekker and Maria Aloni. Cambridge: Cambridge University Press.

Ojeda, Almerindo. 2005. The paradox of mass plurals. In Polymorphous Linguistics: Jim McCawley's Legacy, ed. by Salikoko S. Mufwene, Elaine J. Francis and Rebecca S. Wheeler, 389-410. Cambridge, Mass.: MIT Press.

Papafragou, Anna. 2005. Relations between language and thought: Individuation and the count/ mass distinction. In Handbook of categorization in cognitive science, ed. by Henri Cohen and Claire Lefebvre 255-275. New York: Elsevier.

Pearson, Hazel. 2011. A new semantics for group nouns. In WCCFL 28, 160-168.

Pollard, Carl, and Ivan A. Sag. 1994. Head-driven Phrase Structure Grammar. Chicago: University of Chicago Press.

Press, Ian. 1986. A grammar of modern Breton. Mouton: Berlin.

Press, Ian. 2010. Breton. In The Celtic languages, ed. by Martin J. Ball and Nicole Müller, 427-487. Routledge: London.

Quirk, Randolph, Sidney Greenbaum, Geoffrey Leech, and Jan Svartvik. 1985. A comprehensive grammar of the English language. London: Longman.

Rezac, Milan, and Mélanie Jouitteau. 2015. The ways of a referential impersonal: Consequences of phi-deficiency. Ms., CNRS-IKER.

Rostrenen, Grégoire de. 1732, Dictionnaire François-Celtique ou François-Breton, Roazhon. [2008, Al Lanv].

Rothstein, Susan. 2010. Counting and the mass-count distinction. Journal of Semantics 27: 343397.

Scha, Remko, and Yoad Winter. to appear. Plurals. In The Handbook of Contemporary Semantic Theory, ed. by Shalom Lappin and Chris Fox. Wiley-Blackwell.

Schwarzschild, Roger. 2011. Stubborn distributivity, multiparticipant nouns and the count/mass distinction. In NELS 39, 661-678. Amherst, Mass.: GLSA.

Solt, Stepanie. 2009. Semantics of adjectives of quantity. Doctoral dissertation, CUNY.

Steen, Mark. 2012. The metaphysics of mass terms. Stanford Encyclopedia of Philosophy. On-line: http//plato.stanford.edu.

Stowell, Tim. 2013. Binominal each. In Strategies of quantification, ed. by Kook-Hee Gil, Stephen Harow, and George Tsoulas, 260-294. Oxford: Oxford University Press.

Trépos, Pierre: 1957, Le pluriel breton, Emgleo Breiz, Brest. [1982, Emgleo Breiz edition].

Tunstall, Susanne. 1998. The interpretation of quantifiers: Semantics and processing. Doctoral dissertation, University of Massachusetts, Amherst.

Wierzbicka, Anna. 1988. The Semantics of Grammar. Amsterdam: John Benjamins. 